\title{
A Radical Shift to a Profound and Rigorous Investigation in Political Discourse: An Integrated Approach
}

\author{
Bahram Kazemian ${ }^{1} \&$ Somayyeh Hashemi ${ }^{1}$ \\ ${ }^{1}$ Department of English, Tabriz Branch, Islamic Azad University, Tabriz, Iran \\ Correspondence: Bahram Kazemian, Department of English, Tabriz Branch, Islamic Azad University, Tabriz, Iran. \\ E-mail: bahram_kazemian@yahoo.com
}

\author{
Received: February 5, 2017 Accepted: February 17, 2017 Online Published: March 1, 2017 \\ doi:10.5539/ijel.v7n3p115 URL: http://doi.org/10.5539/ijel.v7n3p115
}

\begin{abstract}
Drawing on overarching methodological frameworks of Hallidayan grammatical metaphor, Fairclough's perspective on critical discourse analysis and rhetoric, this study attempts to posit a novel, integrated and practical approach to political, the media, advertisement and other discourses. To this end and based on the proposed approach, it aims to critically and eclectically exemplify and dissect three speeches delivered by Mr. Barack Obama, former president of the US, to first manifest the integrated approach practicality and adeptness through analysis; then by virtue of analysis to unveil how language is manipulated and distorted by orators in order to convey seamlessly intended messages and political creeds to the audience. Surveying recent annals of literature, to date no one has conducted an integrated study applying these disciplines in an individual paper and this study as a trial one can be useful for upcoming research. The analysis depicts practicality and efficiency of the integrated approach and displays that the speeches abound with nominalizations, modal verbs, parallelisms and antitheses. Furthermore, there are some three-part listing, the use of passivization, quotations and modality metaphors. Therefore, a tendency to utilize more nominalizations, parallelism and other devices by the speaker can be a fundamental reason for making his political language more powerful, impressive, persuasive and ambiguous as well.
\end{abstract}

Keywords: ideational grammatical metaphor, interpersonal grammatical metaphor, critical discourse analysis, rhetorical tropes, Barack Obama, political discourse, ideologies

\section{Introduction}

Language is an indispensable fabric of everyone's life; it is a means of communication, and a social phenomenon by which we can communicate in different ways. The most critical thing in a speech is to influence the actions of the audience (potentially via beliefs, messages, assumptions etc.) by conveying intended messages and assumptions to them. Woods (2006) and Kazemian \& Hashemi (2014) maintain that our social associations are almost entirely realized in language; it is a dominant shaping force in how we think about and construct the world we live in. Since meaning is formulated in our social practice of language, then it stands to reason to claim that a connection between forms and functions of our language is fundamentally flexible and in a state of flux. Our utterances mean what they are taken to mean, and basically collaborative practice of our social conduct certifies that our assumptions and intent are, for the most part, apprehended by those with whom we interact.

Politics and Language are inextricably interwoven. Because of the great impact of politics and the media in everyday life, these discourses have acquired their prominence and worth worldwide. Language can be used to steer people's viewpoints and thoughts to conduct in distinct ways as well as to control the way those people think and believe. Due to the fundamental importance of language in politics and the media, politicians and the press have a tendency to employ particular forms of language to give their discourse allure and enchantment which allow them to transmit multiple notions and dogmas to various people with various orientations and beliefs at one time and within one piece of discourse; to this end and these functions, they manipulate their language in a subtle, objective, ambiguous and persuasive way. Accordingly, they equip their discourse with numerous distinctive attributes to serve its multifacetedness and multi-functionality essence concurrently.

The authors believe that utilizing some strategies and devices from a single framework is a prerequisite but not a sufficient factor for inspection in any texts and talks. Therefore, for thoroughly locating hidden ideologies in texts and talks, an amalgamation of different apparatus should be applied. Nevertheless, in order to investigate 
such discursive discourses viz politics, advertisement, the media etc., a coalescence of rigorous and interdisciplinary analytical disciplines such as Systemic Functional Linguistics (SFL), Critical Discourse Analysis (CDA) and Rhetoric are necessarily required. The rationale behind this choice and advantages of this integration, in comparison to other studies, can be that examining and perusing any kinds of texts from three-pronged disciplines along with their multiple sub-divisions and aspects can open up ample opportunities for researchers to sift through various texts and unmask more covert ideologically, politically and religiously-charged notions disseminating all over them. As Blommaert (2005 p. 14) claims "in developing a critical science of language, we should at least take stock of what is around". This study is a bid to throw more light, by proposing an integrated approach as well as offering a grab bag of reasons, on the upcoming investigations to consider the posited integrated approach and to coalesce various strategies for a methodical and scrupulous analysis.

\section{Literature Review and Theoretical Frameworks}

SFL was founded in 1970s by Halliday which is a theory about language as a resource for creating meaning based on a context of situation and a context of culture and is pivoted on the notion of language function (Kazemian, 2014). This distinct procedure to the study of grammar is salient because it narrows the gap between social and linguistic structure in a precise manner. The basic supposition engulfing SFL is that form and function of grammar play a vital role in discourse formation and there is also a selection of linguistic choices available to fulfill various instances of social needs. Butt et al. (2000), Bloor \& Bloor (2004) postulate that language, in SFL, is constructed to generate three major sorts of meanings or metafunctions: Ideational, Interpersonal and Textual. The whole model of SFL is based upon a close relationship and interaction between these metafunctions. It is worth noting that Grammatical Metaphor (GM) is distinguished in terms of metafunctions. In fact, it is a conversion of one grammatical form, or one construct by another. Linguistically, GM is twofold (Halliday, 1994), i.e., Ideational and interpersonal.

Ideational GMs are known as metaphors of transitivity. The grammatical variation between metaphorical and congruent wording applies to transitivity layouts and can be inspected in terms of the functional constituent of these layouts. Thus, transitivity elaborates various types of processes that are realized in language, and the structures by which they are stated. There are six types of processes in English: material, mental, relational, verbal, behavioral and existential. Ideational and interpersonal GMs have different but complimentary essence. Generally, Interpersonal GM is categorized into two kinds based on semantic function: mood and modality metaphors, with the former denoting the speaker's objective to be accomplished with his speech while the latter, based on semantic correlation of projection, representing the speaker's appraisal or judgment which falls in the intermediate degrees between positive and negative polarity (Halliday, 1994; Taverniers, 2002).

In harmony with SFL, Fairclough's approach (2001) to CDA is prominent because it grapples with textual materials and its profound impact is on monitoring grammatical facets of discourse. Thus, the association between discourse and social responsibilities can be revealed through a grammatical analysis of clausal configurations. According to Fairclough, society not only instantiates discourse but it is also instantiated by discourse; that is, discourse constructs the way people think, and the linguistic characteristics also, as vehicles, convey ideological attitudes and conceptions of the social world. By way of illustration, Woods (2006) discusses that CDA endeavors to scrutinize language as a form of cultural and social practice, and it is an approach allowing the elaboration and interpretation of social life as represented in talks and texts. Woods also asserts that CDA concentrates particularly on the association between power and discourse, studying the way in which, as van Dijk (2001, p. 352) argues, "social power abuse, dominance, and inequality are enacted, reproduced, and resisted by text and talk in the social and political context".

Therefore, there is a close affinity between SFL and CDA in which they share some common properties; as such, "they share a view of language as a social construct, looking at the role of language in society and at the ways in which society has fashioned language and studying how meanings are made in various contexts" (Young \& Harrison, 2004, p. 1). They also show highest inclination to deconstruct covert ideology in a text and to concentrate on linkages between ways of talking and ways of thinking.

Of all other disciplines, CDA and Rhetoric seem to be firmly bound up with political text analysis. CDA is centrally interested in language in its socio-cultural context and embedded ideologies within discursive practices that is established through interaction and texts. Rhetorical analysis, on the other hand, restricts its scope to political interaction and is inclined to look into patterns of assumptions displayed in persuasive compositions (Richardson, 2004; Jost \& Olmsted, 2004; Johnstone \& Eisenhart, 2008). For through exploitation of various strategies and tactics, orators have a tendency to come to a proper understanding with their addressees through 
purposive persuasiveness as an art of rhetoric (Fairclough, 2003).

As discussed, three fashionable approaches to the analysis of political texts are CDA, SFL, and Rhetoric in which strong interdisciplinary ties exist among them. Surveying recent practical research annals of literature in SFL, CDA and Rhetoric indicates that there are numerous valued papers teasing these disciplines out individually (but not collectively) in a single paper with some corpora in various discourses and with some significant results. Technically, these articles, based on their design, can be subsumed under two categories as follows:

1) Descriptive-Analytical: analyzing a text with two or some devices in one genre within a single discipline such as Rhetoric, CDA or SFL e.g. investigating modality or GM in political or scientific texts etc. (Murphy, 2003; Xu, 2009; Ye, 2010; Wenyan, 2012; Kazemian et al. 2013; Ehineni, 2014; Zheng, 2014; Noor et al., 2015; Ali \& Kazemian, 2015; Ali et al., 2015; Zhou \& Kazemian, 2015 etc.);

2) Comparative-Analytical: analyzing and comparing two different texts in same genre or different genres with two or some devices within a single discipline e.g. investigating and comparing rhetorical devices or GM in scientific and political texts etc. (Flowerdew, 2002; Lillian, 2008; Seo, 2013; Kazemian \& Hashemi, 2014; Kazemian, 2014; Ezeifeka, 2015 etc.).

However, the authors believe that in order to unmask and unravel multidisciplinary discourses viz politics, the media, advertisement etc., a multifarious and meticulous approach is required to scrutinize any texts and talks so that to grasp much more embedded ideological notions and intentions of orators and the press. Consequently, drawing on the overarching methodological frameworks of Hallidayan SFL, Fairclough's perspective on CDA and rhetoric, this study attempts to propose an integrated and practical approach to sift through the above discourses profoundly and unveil how language is manipulated by the orators and the press in order to provoke, emphasize, conceal, signify differentiation, convey seamlessly the intended messages and political creeds to the audience and even to call their heed to burst into rapturous applause at the right time. Hence, to narrow the gap and introduce a practical approach to upcoming investigations in the above-mentioned discourses, this study attempts to show what the collective consideration of CDA, SFL and Rhetoric could offer and posit another category as a shift to a discerning and critical inspection as follows:

3) Elaborative-Integrated-Analytical: an elaborate and exhaustive analysis of one or more texts in one or more genres with multiple and integrated devices, as a different idea arising from the confluence of GM or other frameworks in SFL, CDA and Rhetoric. It should be born in mind that there are no specific parameters for the integrated approach and the choice of strategies from the proposed frameworks depend on the pertinent discourse, text and talk; as such, due to the employment of archaic, arcane and ritualistic forms and words in encrypted code of legal language, few rhetorical tropes and apparatus (antithetic parallelism) might be deployed in the discourse of law and instead, multiple devices from the other disciplines such as GM, Attitudinal positing, modal verbs etc. might be employed. Thus, selection of germane strategies and tropes must be carried out by perusing related texts and talks by researchers.

However, some attempts have been made to examine various texts and have gone farther and deeper than the surface glitz, and have coalesced only two of frameworks, i.e., CDA with SFL or with Rhetoric with a few devices in a single paper (De Cillia et al. 1999; Pu, 2007; Wang, 2010; Gunawan, 2010; Zhao, 2011). In accord with this approach, to date no one, likely due to its challenging and demanding essence, has conducted an integrated study applying these disciplines in an individual paper; and this study as a trial one can be useful for upcoming research.

Therefore, this study, based on the proposed integrated approach, aims to critically exemplify and dissect three speeches delivered by Mr. Obama, to first manifest its practicality and feasibility through analysis; then by virtue of analysis to reveal how and why different types of strategies are distributed and, finally on the basis of chosen apparatus, to pinpoint their inter-related functionalities, effectiveness and frequency in the texts.

\section{Methodology}

\subsection{Corpus}

It is presumed that familiarity with context can aid readers to comprehend coherent relationships across utterances. Thus, due to their nationwide and worldwide political salience, three speeches, approximately 12270 words, are selected to pinpoint featured devices' inter-related and multifaceted functionalities, efficiency and frequency. The first one is Mr. Obama's second presidential inaugural address delivered in 2013, 21 January in Washington, D. C (2125 words); the other speeches are his 68th and 69th Sessions of the United Nations General Assembly Addresses, delivered 24 September 2013 and 2014, in New York (4541 \& 5604 words respectively), 
which are meant to the international community (available at: http://www.americanrhetoric.com/barackobamaspeeches.htm).

Criteria for choosing political discourse as the sample and Mr. Obama's speeches are manifold: (a) the "salience", multidisciplinary and multifacedness of the discourse of politics (Wodak, 1989); (b) few politicians' speeches are much more dominant and effective than his rhetoric, (c) since his remarks have a ripple effect through the whole international affairs; (d) his addresses are succinct but precise, with no circumlocutions; (e) like most of political speeches, his are discreet, pre-planned and tactful, (f) they also abound with a heterogeneous collection of religious, political and ideological creeds, ( $g$ ) unlike the others, they are steeped in various strategies and discursive tropes; (h) eventually, in comparison to most of his predecessors, he has formidable political skills and impressive oratorical powers.

\subsection{Procedure}

The researchers perused the speeches to identify what strategies have been predominantly used by spin-doctors and orators. After reading the texts with scrutiny, the following featured tropes and tools such as some rhetorical devices, passivized phrases, modality metaphors, modal verbs, nominalizations etc. are spotted; then they are analyzed to determine their functions and frequency in the texts; after that the nominalized phrases are congruently reworded to recognize their process types afterward where the ideas of Halliday (1994), Martin et al. (1997), Thompson (2004), Halliday \& Matthiessen (2004), and Webster (2004) are employed as the most catholic benchmarks to analyze nominalization, because Halliday (1994) argues that for identifying process types, each metaphorical domain must have its counterpart congruent wording.

\section{Data Analysis and Discussion}

The exemplified and dominant featured tropes and strategies of this study are Ideational GMs (nominalization and process types), modality metaphor in interpersonal GM, modal verbs, politeness theory, passivization, unification strategy (we-groups), the use of quotations in CDA and some rhetorical devices such as parallelism, three-part lists, antitheses, and lexical and textual analysis, each of which will be discussed in the following. These devices are pinpointed and analyzed in three speeches to illuminate practicality, adeptness and efficiency of the proposed integrated approach in the discourse of politics which is generalizable to other discourses as well.

\subsection{Ideational GM}

It should be noted that non-congruent variation in SFL is lexico-grammatical rather than simply lexical (Halliday, 1994). To Thompson (2004, p. 223), GM is "the expression of meaning through a lexico-grammatical form which originally evolved to express a different kind of meaning". In metaphorical or nominalized clauses, there is a general inclination toward thingness. Through nominalization, processes (verbs) and properties or qualities (adjectives) are construed metaphorically as entities, allowing an informationally dense discourse. To Halliday (1994, p. 352), nominalization is "the single most powerful resource for creating GM"; accordingly, Simon-Vandenbergen et al. (2003) and Kazemian \& Hashemi (2014) argue that GM of nominalization is a language resource utilized to condense information by dispatching notions in metaphoricity which is much appreciated as a way of uttering objectification, abstractness, ambiguity, lexical density, formality as well as a mark of prestige and power, e.g.:

(1) a. Our celebration of initiative and enterprise, our insistence on hard work and personal responsibility... (text 1).

b. And we must be a source of hope to the poor, ... the victims of prejudice — ... because peace in our time requires the constant advance of... creed describes: tolerance and opportunity, human dignity, and justice (text 1).

c. Our overriding interest throughout these past... the will of the Egyptian people, and recognizes true democracy as requiring a respect for... freedom of speech and assembly...

The above excerpts from the texts explicate clearly that nominalization principally enables spin-doctors and orators to encode and transform dynamic processes (to change, try, destroy, insist, work etc.) and qualities (responsible, violent, peaceful etc.) into static concepts and entities (change, destruction, insistence, responsibility, ignorance etc.) through re-classification and metaphorization. Thus, nominalization is the conversion and representation of processes and qualities as entities with critical ramifications of curtailment, abstractness, objectivity, generalization, impersonality, language economy, informational richness, beauty, exclusion of social actors etc. of the clauses (Kazemian et al., 2013; Kazemian, 2014). 
The above examples demonstrate that nominalization can cloud or remove agents allowing speakers to conceal responsibilities of actors. It also augments lexical density and information load of clauses by compassing and shrinking information causing ambiguity and complexity in texts. Mr. Obama could not convincingly and reasonably convey his intended notions to the audience through the congruent realm. Out of 1145 nominalizations in three speeches, 502 go for material, 457 for relational, 97 for mental, 75 for verbal, 12 for behavioral and 2 for existential processes as follows:

Table 1. Frequency \& percentage of process types in texts 1, 2, \& 3

\begin{tabular}{lllllllll}
\hline Process types & $\begin{array}{l}\text { Frequency } \\
\text { (text 1) }\end{array}$ & Percentage & $\begin{array}{l}\text { Frequency } \\
\text { (text 2) }\end{array}$ & Percentage & $\begin{array}{l}\text { Frequency } \\
\text { (text 3) }\end{array}$ & Percentage & $\begin{array}{l}\text { Frequency } \\
\text { (all) }\end{array}$ & $\begin{array}{l}\text { Percentage } \\
\text { (all) }\end{array}$ \\
\hline material & 67 & 3.15 & 263 & 4.6 & 172 & 3.78 & 502 & 4.09 \\
relational & 82 & 3.86 & 207 & 3.6 & 168 & 3.69 & 457 & 3.72 \\
mental & 15 & 0.70 & 42 & 0.74 & 40 & 0.88 & 97 & 0.79 \\
verbal & 12 & 0.56 & 38 & 0.67 & 25 & 0.55 & 75 & 0.61 \\
behavioral & 0 & --- & 8 & 0.14 & 4 & 0.08 & 12 & 0.09 \\
existential & 0 & --- & 1 & 0.01 & 1 & 0.02 & 2 & 0.01 \\
Total & 176 & 8.29 & 559 & 9.96 & 410 & 9.02 & 1145 & 9.33 \\
word count & 2122 & --- & 5608 & --- & 4541 & -- & 12271 & --- \\
\hline
\end{tabular}

As Table 1 shows, the most featured process types in these texts are types 2 and 1 (see Webster, 2004, p. 41), i.e., being process to entity (oppose to opposition), and being quality to entity (violent to violence) respectively; and the most dominant processes are material (502) and relational (457). Nominalizations in these texts amount to 1145 clauses and the proportion of all processes to the whole words is $9.33 \%$. This excessive exploitation of both material and relational types is quite critical and remarkable in terms of power relations. For Halliday \& Matthiessen (2004) suggest that for deployment of dominance, it is more imperative to dispose it within domain of doing rather than other processes.

\subsection{Modality Metaphor}

While Ideational GM results in encapsulation of wording, Interpersonal GM leads to expansion of it (Thompson, 2004). Although they have different directions in terms of grammatical transformations, both of them arise from remapping between semantics and lexico-grammar. Halliday (1994), on the basis of different communicative functions, discriminates modalization from modulation. The former serves to present speaker's judgment on the probability and frequency of statements, incorporating rank of likelihood (possibly, probably, certainly) and rank of usuality (often, sometimes, always); the latter serves to present speaker's judgment on the expectability of a suggestion, incorporating rank of obligation (allowed, supposed, required) and rank of inclination (willing, keen, determined). Due to pertinence of polarity to value, Halliday consigns low, middle and high values to the above ranks respectively (Xu, 2009). Eventually, Halliday (1994) distinguishes a couple of orientations including subjectivity and objectivity, and explicitness and implicitness variants. In other words, there are four respective options in modalization and modulation, including subjective (I think) and objective (it is usual) explicit modality, and subjective (will, should etc.) and objective (probably, supposed to, keen to etc.) implicit modality.

On the basis of Hallidayan SFL, modal values can be construed non-metaphorically by modal verbs (will, must, might, can etc.) and adjuncts (perhaps, possibly, certainly) and metaphorically through more lexical structures as follows:

(2) a. We believe that right makes might.

b. It's far more likely that without international action...

c. We are also determined to resolve a conflict that...

Modality orientation pertains to speakers' modal accountability, i.e., how much explicit accountability speakers hold for their attitudes and judgment (Thompson, 2004). Indeed, both subjective and objective explicit orientations concern metaphoricity. In other words, implicit orientations or congruent realizations express modality implicitly while metaphorical realizations express modality explicitly. By exploiting explicit subjectivity, modality clauses attach significance to orator's subjective attitudes and make them accountable for their embedded judgments, whereas by explicit objectivity his direct responsibility would be avoided and diminished. In order to reduce the distance with the audience, Mr. Obama mainly employs subjective explicit along with we instead of $I$. 
In addition, nominalization of modality can also be utilized to convey objective explicit orientation to construct thingness. Nouns, such as possibility, probability, likelihood, certainty, obligation, regularity, willingness, desire, determination, need etc., are often applied to enunciate probability and inclination as follows (Xu, 2009):

(3) a. So the time is now ripe for... Already, Israeli and Palestinian leaders... willingness to take significant political risks.

b. You and I, as citizens, have the obligation to shape the debates of our time-not only with the votes we cast, but with the voices we lift...

As shown in above examples, by means of constructing the modal meaning as an entity and building modality into undeniable facts, the speaker succeeds in hiding the source of modality and making it objective and explicit; in the meanwhile, nominalization is used to eliminate the speaker's entailment, keeping the probability or certainty of modality meanings out of his reach. The analysis displays that modality metaphor's expressions are used 164 times in the texts, and the most featured ones are subjective metaphors implying the speaker's struggles to opine and emphasize his own or his administration's outlooks and ideological creeds to the audience and to take responsibility for his viewpoints. By dint of subjectivity, the speaker foregrounds his subjective presence in the communicative process and seeks to create an interpersonal affinity with the crowd in the sense that the audience must see this personalised interaction as in some way pertinent, salient, valid, justified or at least understandable. Once such an empathetic rapport has been initiated, then there is the possibility that the listener will be more open to the broader ideological aspects of the speaker's orientation.

\subsection{Modality (Modal Verbs)}

Regarding Eggins's (2004) and Renkema's (2009) views, they maintain that modality is the conveyance and imposition of a language user's or an orator's opinions and attitudes to the audience. Modal verbs (might, shall, will, must, ought to, need to etc.) are exploited with other verbs to express ideas such as possibility, permission, obligation or intention with high, median and low values as in Table 2. Modality is expressed in all languages through either grammatical mood or modal systems (or both), and it is the degree of certainty about an incident, action or a state of affairs.

Table 2. Modality values (adopted from Halliday \& Matthiessen, 2004, p. 622)

\begin{tabular}{llll}
\hline & Low Politeness & Median Politeness & High Politeness \\
\hline Positive (P) & Can, may, could, might & Will, would, should, shall & $\begin{array}{l}\text { Must, ought to, need, has/had to } \\
\text { Negative (N) }\end{array}$ \\
needn't, need to, have to & Won't, wouldn't, shouldn't & $\begin{array}{l}\text { Mustn't, oughtn't to, can't, couldn't, mayn't, } \\
\text { mightn't, hasn't/hadn't to }\end{array}$ \\
\hline
\end{tabular}

Table 3. Modality analysis of the speeches

\begin{tabular}{lllllllllll}
\hline texts & total & \multicolumn{3}{c}{ Low Politeness } & \multicolumn{3}{c}{ Median Politeness } & \multicolumn{3}{c}{ High Politeness } \\
& & $\mathrm{P}$ & $\mathrm{N}$ & total & $\mathrm{P}$ & $\mathrm{N}$ & total & $\mathrm{P}$ & $\mathrm{N}$ & total \\
\hline 1 & 2122 & 13 & 2 & 15 & 23 & 0 & 23 & 16 & 6 & 22 \\
2 & 5608 & 40 & 5 & 45 & 55 & 6 & 61 & 15 & 17 & 32 \\
3 & 4541 & 30 & 1 & 31 & 51 & 8 & 59 & 15 & 5 & 20 \\
Total & 12271 & 83 & 8 & 91 & 129 & 14 & 143 & 46 & 28 & 74 \\
percentage & & 0.67 & 0.06 & 0.74 & 1.05 & 0.11 & 1.16 & 0.37 & 0.22 & 0.60 \\
\hline
\end{tabular}

The above Table 3 depicts the modality analysis of the speeches based on modality values. The most frequently featured modal verbs in the texts are will, can and must signaling the speaker's judgments of probabilities, permission, and necessity respectively. To Fairclough (2001), modality is the enunciation of the language users' authority and dominance which is twofold based on its orientations: relational and expressive, the former incorporates the authority of one participant concerning others, and the latter includes "the speaker or writer's authority with respect to the truth or possibility of a representation of reality, i.e., the modality of the speaker or writer's evaluation of truth" (p. 126). Consider the following examples:

(4) a. If we cannot agree even on this, then it will show that the UN..., it will send a powerful message...

b. The roadblocks may prove to be too great, but I firmly believe the diplomatic path must be tested. For while the status quo will only... path will be good for the region and the world, and will help...

By using high negative modality (the example 4a) (cannot: denoting obligation), the speaker makes an effort to 
tempt and convince the crowd to pass a resolution calling for a ban and annihilation of chemical weapons by Assad Regime, otherwise, they will be accused of being incompetent and inept to do so (using will to refer to its international serious repercussions). In the example (4b), by dint of must, he inculcates his outlooks and ideology overtly and then covertly into the audience, as if he is dictating and imposing what he wants the audience to do where it seems that they cannot help defying but agree with him.

Therefore, it stands to reason to claim that the existence of implicitness (modal verbs) and explicitness (metaphorical) modality at any texts implies that every discourse, written or spoken, is attitudinal-oriented, and no text is free from this orientation; modality metaphor refers to orators' judgment and appraisal about a fact over the audience. Moreover, it indicates orators' conceptualized and internalized world views and ideologies whereas employing modal verbs refer to the orators' authority, power and dominance, each of which insinuating the obligatory, attitudinal or probable essence of delivered facts imposed on the audience.

\subsection{Politeness Theory}

Thompson (2004) obviously highlights that the source of modality in a text is its speaker. Any modality is a manifestation of the speakers' personal viewpoints rather than objectified fact. By utilizing modalization, speakers recurrently exhibit signs of politeness towards others. Besides, to soften the blow of face-threatening acts and to voice their utterance in a polite form, orators, the press and advertisers are extremely punctilious about the coinage, crafting and engineering of particular linguistic strategies and oblique clauses (it is possible that...). The employment of subjective and objective modality metaphors is of paramount importance to express politeness degree in interactions. The more indirect phrases, the higher degree of politeness will be. Besides, objective explicit metaphors allow speakers to distance themselves from the audience while leaving the crowd to sense that the judgment on the statements is outside their remit (Brown \& Levinson, 1987).

\subsection{Passivization}

With the primary aim of unmasking relationships among language, society, power, and ideology, CDA provides a lens with which a researcher can disclose structures of power and also uncover ideological dogma and power connections in various texts and talks. One ubiquitous strategy in CDA is the use of passive voices, i.e., agentlessness in clauses; by means of this device, and as the staple diet of nearly all political and media discourses, actors can be relegated or removed totally in propositions bringing about ambiguity and concealment as follows: (Beard, 2000; van Dijk, 2000)

(5) a. Freedom must be secured by his people here on earth.

b. Innocent children have been gunned down. Bodies have been dumped in mass graves. Religious minorities have been starved to death. ... innocent human beings have been beheaded...

In the above excerpts, actors in the example (5a) are downgraded and the action (freedom) is foregrounded. Whereas, in the example (5b), the participant(s) is entirely omitted to conceal the agency of such gross and obnoxious misdeeds. There are 130 passivized expressions in the texts in which the agents are deliberately backgrounded or removed to gloss over maltreatment. Thus, it can be claimed that such apparatus encodes ideological partiality in favor. In the meantime, individuals in charge of misconduct are devalued and screened from the scene of crime or action by orators, and from the audience or readers as well (Kazemian \& Hashemi, 2014). In complementarity with the agentlessness of phrases, nominalization can also be deployed to compact information and to blot participants out of the scene and make clauses objectified and more ambiguous (Cook, 2003) (e.g., dumping bodies in mass graves). Fairclough (2003) points out that the exclusion and inclusion of social actors can be syntactically distorted. He comments "there are many motivations for exclusion, such as redundancy or irrelevance, but exclusion may be politically or socially significant" (p. 149).

\subsection{Unification and Cohesivation Strategy (we-groups)}

It has been argued that strategic deployment of we-groups (we, us and our), signaling solidarity and power, in political discourses not only operates to construct a personalized or inclusive association between orators and the crowd, but also due to its vagueness, it can serve to exclude or depersonalize agents of political action making it intricate to identify the exact referents of $w e$ in propositions as follows: (Fairclough, 2001; Woods, 2006).

(6) a. For now decisions are upon $u s$ and we cannot afford delay. We cannot mistake... We must act, knowing that our work will be imperfect.

b. We will use our military might... We will train and... We will work to cut off.

Knowing salient roles of we-groups in establishing a sense of solidarity of speakers with the crowd, Mr. Obama prefers we-groups in his speeches more than other pronouns. Due to their utilizations based on orators' great tact 
and their context-dependency nature, recognizing the orientation of we-groups (their inclusiveness and exclusiveness) is somehow a challenge; for they are sometimes applied to refer to the speaker and his administration incorporating his authority and power hierarchy, and at times are used tactfully and strategically to associate himself with the audience and share his remarks and their repercussions with them. In the above example (6a), the speaker has used inclusive ones ( $u s$ and we) to include and unite himself with the audience; in this case, he considers himself as their representative and addresses the speech in behalf of them and he tries to apportion responsibility and decisions between them. However in the example (6b), he clearly delineates boundaries between his administration, as an authority, and the people by exclusive we-groups. We, us and our(s) are deployed 265, 47 and 186 times respectively (4.05\%) in the texts and are, probably, some of the most frequently featured words of the speeches.

\subsection{Parallelism, Anaphora and the Power of Three}

To Gandio (2008), persuasion entails at least three phases: it can alter, constitute and maintain someone's opinions. Language determines our comprehension, perception and thus our orientation to the world. In other words, language comprises awareness. Initiated for persuasive effect and in part for aesthetic impact, rhetorical tropes viz parallelism contain instances of syntactic and lexical patterning of language and it also adds melodic-like and cohesive structures to speeches. Like nominalization and other devices, parallel and three-part structures are intentionally disseminated through the texts as the following examples:

(7) a. societies based upon democracy and openness and the dignity of the individual will ultimately be more stable, more prosperous, and more peaceful.

b. I often tell young people... than ever before to be literate, to be healthy, to be free to pursue your dreams.

c. ... address their differences directly, honestly, and peacefully across...

These parallel compositions can make Mr. Obama's speeches magnificent and awe-inspiring, and the speeches can manifest influential political rhetoric and oratory through parallelism. Mr. Obama, in one example in text two, commences one of the clauses with (I believe we can embrace a different future...), and in order to explicate his objectives, he has used four parallel constructs starting with (through...), as solutions to convince the crowd of how to achieve different future in a brilliant and transparent way.

In another example, as a prologue, he begins to convey his outlooks and addresses the audience by this introductory sentence "It is now our generation's task to..." and as an epilogue, he finishes his expression by the same words: "That is our generation's task to..."; to this end and to bridge the gap between them, he has deployed five compositions of parallel constitute (our journey is not complete until...) and by employing parallelism and anaphora, he not only expresses and dictates implicitly and indirectly his orientation and ideologies to the audience and his opponent party but also he strives to emphasize the generation's major task, to persuade them and beautify his speeches by parallelism as well.

Some parallel structures are extremely flamboyant and distinctive in the texts. Parallel structures, in one instance, unify six relevant short paragraphs and create cohesion between them; the rationale behind their use might be that the orator exhorts the crowd in order to grab quickly the growing importance of issues and reflect upon them. They are also deftly applied in cohesive paragraphs or clauses to express his political assumptions in a protruding and vivid way. In another instance, by applying where-and-then, and four because clauses as parallel constituents in a row (text 3), he strives to signify the crux of problems by cause-and-effect relations and make the audience zero in on the depth of thorny problems all people have encountered; he also exemplifies these issues by we see it in ... where clauses to convince the crowd and to substantiate his claims as well.

Thomas \& Wareing (2004, p. 49) state that "audiences and speakers seem to find linguistically grouped features and especially those in threes, aesthetically pleasing". Rhetorically, three-part listing is one of the number of distinguished tropes, well-known to orators, which fall under the heading of parallelism. By disposing parallel constructions and the rule of three in sequences, they not only add clarification, unification, impression, efficiency and beauty to the sentences as well, but also they are readily lodged and stuck in the brain of the audience. They also create familiar clap-trap rhythm that the audience realizes as both persuasive and appropriately political (Atkinson, 1984; Woods, 2006; Kazemian, 2015).

Moreover, repetition and three-part statements are used in the speeches to emphasize particular points and to make speeches more memorable and catchy for the audience as in the examples (7a, b and c above). Mr. Obama's last words, in text three, are replete with parallel structures and can be characterized as slogan-like expressions which are uttered intentionally to draw the crowd's attention to his political creeds and convictions. All these structures in the speeches amount to 201 clauses (text one: 47, text two: 67, text three: 87) denoting 
that they cannot be expressed impromptu and must be pre-planned and stage-managed and written by a deft orator or a spin-doctor considering the audience and context.

\subsection{Antithesis}

By way of illumination, Beard (2000) argues that political speech is an implausibly complicated work of well-thought-out words, timely ideas, appropriate accentuation, fluid transfer and charming personality, all selected to persuade the crowds. Abrams \& Harpham (2009, p. 14) clarify exactly what is meant by antithesis and define it as a "contrast or opposition in the meanings of contiguous phrases or clauses that manifest parallelism". It is a strategy used by Mr. Obama to fortify his rhetorical impact and emotive force of his oratory as in:

(8) a. We come together at a crossroads between war and peace; between disorder and integration; between fear and hope.

b. You come from a great tradition that stands for education, not ignorance; innovation, not destruction; the dignity of life, not murder.

c. This is a vision of the world in which might makes right.... We believe that right makes might-that bigger nations should not be able to bully smaller ones, and that people should be able to choose their own future.

The above examples $(8 \mathrm{a}, \mathrm{b})$ not only depict parallelism and the power of three, but also antithesis compositions in which contrasts are drawn between the elements that are paralleled. Commencing his speech (text three) with three persuasive tropes (the example a) in one clause viz parallelism, three-part list and antithesis can be tellingly influential, impressive and mesmeric for the crowd and can call their heed to take the speaker's remarks into account. Besides, by using three antitheses, parallelism (that... clauses) and integrating it with modality metaphors (believe that) in one paragraph in the example (9c), Mr. Obama implicitly deplores Russia's bullying Ukraine and attempts to inculcate and intimate his own attitudes and ideologies to the audience. His deft and deliberate employment of inclusive we, which is controversial, indicates his oratorical talent making an effort to incorporate all the audience into his ideology as if he delivers the speech on behalf of them; the controversy surrounding we is that it can both refer to his administration and the audience or both.

A large number of antitheses (111 phrases) in the texts are deliberately and carefully juxtaposed to signify contradictory remarks and to take the paramount importance of the past or current issues into the audience's account in order to ponder upon and distinguish facts from fictions, falsehood from truth and also to judge merits of a definite and systematic relationship between ideas.

\subsection{Lexical and Textual Analysis}

It can be noted that the terms lexical and textual analyses (in this study) are generally understood to mean to critically delve deeper into the speeches and to concentrate on more detailed points in terms of coherence, instances and functions of the most frequent and specific words, of deliberate disposition of emotionally, politically and religiously charged terminology embedded within, between or behind lines, of the speakers' tone and mood, and of using quotations etc.

The content of Mr. Barack Obama's speeches differ from each other based on challenging issues at that time and specific addresses; for instance, his first speech is a momentous occasion for him, and it would have a great impact on his presidency tenure from those addressed in the UN General Assembly in 2013 and 2014. It is assumed that orators and spin-doctors are extremely assiduous and meticulous in preparing all kinds of speeches, thereby knowing the audience is of paramount importance for them to coin a language pertinent to the particular crowd's tendencies and interests in order to persuade and even mobilize them to concur with speakers' political ideologies and attitudes. Consequently, to accomplish the objective of convincing nationwide and worldwide that he, as the incumbent president of the U.S, along with his party were and are competent, qualified and proficient at leadership, he first (text one) illuminates his administration's past achievements and then his current planned policies and affairs, both internal and external, in a formal, persuasive, compelling and sometimes truculent way (Wang, 2010).

It is worthwhile to note that the whole texts show great coherence and cohesion, validity and rationality in terms of content and arguments, so that it would be easier for the public to digest and take the speaker's intended concepts and assumptions in and also for the speaker to encourage the audience to embrace and support his policies.

While perusing the texts, the researchers discerned that some words or clauses are used much more frequently than the others for specific addressees and particular objectives. It stands to reason to claim that copious and 
abundant utilization of particular words in the speeches might symbolize and mirror the speaker's chief preoccupations, his concerns about international strife, predicaments and unrest, and his ambitions and ideologies about them as well. For example, in text two, he covertly states his attitudes toward Iran and Russia by dint of metaphors of modality (It's time for them to realize that...) implying that they must abandon their attempts to insist on Assad's rule; in the following clauses, his words also insinuate that Iranian government must meet its responsibilities under the NPT as well, otherwise Iran's isolation will be deepened and more sanctions will be enforced. His tone of speech is not aggressive this time but soft and gentle (likely due to Iran's cooperation in nuclear talks). Consider the following frequently featured words in the texts:

Table 4. Most frequently used words in three speeches

\begin{tabular}{llllll}
\hline Words & Frequency & Words & Frequency & Words & Frequency \\
\hline people & 75 & international & 24 & economy & 16 \\
America & 73 & Muslim/Islam & 24 & change & 16 \\
peace & 52 & freedom & 22 & future & 15 \\
nation & 48 & Israel & 21 & generation & 13 \\
war & 47 & effort & 21 & sectarian & 12 \\
believe & 31 & interest & 19 & democracy & 12 \\
live/life & 30 & young & 18 & politics & 12 \\
Iran & 29 & challenge & 17 & extremist & 11 \\
terrorism & 27 & action & 17 & regime & 11 \\
conflict & 26 & security & 17 & dignity & 10 \\
power & 25 & violence & 17 & progress & 10 \\
new & 24 & nuclear & 16 & hope & 10 \\
\hline \multicolumn{5}{l}{ Positive \& Neutral: $723-5.89 \%$ Negetive: $144-1.17 \%$} \\
Total No.: $867 ;$ Percantage: $7.06 \%$ & \multicolumn{5}{l}{} \\
\hline
\end{tabular}

Regarding Iran's nuclear program and the Israeli-Palestinian acute conflict in 2013, he referred to Iran's name 26 times and Israel's names 15 times, definitely based on his major concerns and current international issues; the tone of his speech is lenient and moderate, whereas in text three (due to P5+1 and Iran's desirable negotiations in 2014), he mentioned Iran' name three times and Israel's name six times, since his chief concerns were Russia and Islamic State (IS) in which he used Islam and Muslim 16 times and Russia 10 times respectively noting that the tone of his speech is belligerent and menacing this time. At first, he is implicitly and then explicitly threatening and alerting Russia's government to call a halt to the interference, occupation and invasion in Ukraine's territory, otherwise, a global war might be declared against them as in:

(9) a. It would take another World War to roll back the forces of fascism, ... no nation can subjugate its neighbors and claim their territory.

b. We will impose a cost on Russia for aggression, and we will counter falsehoods with the truth.

At the commencement of his speech in text one (Inaugural Address), he sets a premium on his country and its people attempting to represent U.S as a perfect embodiment worldwide (What makes us exceptional, what makes us America is...) which can be regarded as overstatement and hyperbole in essence and as a policy to satisfy the audience and lavish them with profuse compliments.

As Table 4 presents, his tone is mainly less aggressive for nationwide and worldwide crises and issues through the texts, and he tends to dispose more positively charged words than negatively loaded ones (using major positively-charged words 723 times more frequently), denoting his clever tactics to prioritize and place premium on people's wellbeing, peace, security, prosperity etc. Moreover, his language is official and ceremonial, for example, he ritualistically uses formal titles rather than names throughout his speeches, and focuses on courtesy and order. Besides, the mood of his speeches are generally thought-provoking and altruistic where he struggles to establish rapprochement among nations all over his speeches; in such and so, he endeavors to develop joint intimacy and rapport with the audience and go through their heads and hearts by means of different tropes (by dint of we-groups for instance), which have big values embedded in political and media discourses.

Another exceptional device is the exploitation of quotations and heroic figures in the speeches (9 quotes), chiefly from Martin Luther King. Accordingly, Atkins \& Finlayson (2014) state that "quotations are not only a source of authority, but a way of claiming authorization"; and by referring to Martin Luther's dream and Nelson Mandela enduring (text 2) or using the U.S Declaration at the beginning of his speech (text 1), he principally 
tends to gain credibility and authorization to his arguments or to equate his speech and endeavors with them. The quotes can also be regarded as flashbacks to provide nostalgic and emotional feelings for the audience and to validate his statements by tailoring those quotations to his current discussions.

Last but not least, as Wang (2010) argues, direct or indirect prayers in the speeches, from Bible, Jesus etc. can all assist "the speaker to win the sympathy and supporting of the audience and make the speech full of charisma". By referring to GOD five times in text one and twice in text three, Mr. Obama's religious creed and convictions are readily perceptible. Furthermore, in text three, he resorts to a command based on words of Jesus (Do unto thy neighbor as you would do-you would have done unto yourself) to justify his expressions and also to convince the audience and all religions to accommodate devout faith with a modern, multicultural world and to eradicate war at its most fundamental source as well.

\section{Conclusion}

The purpose of the current study was to determine practicality and workability of the proposed integrated approach in political discourse by analyzing various devices which can be generalized into other political texts and other discourses viz the media and advertisement etc. In this paper we have analyzed ideological components embedded in three addresses of Mr. Barack Obama; the analysis is grounded in Fairclough's notions of ideology and importance of observing the grammatical aspects of discourse, Hallidayan GM in SFL and some rhetorical devices. It is worthwhile noting that generalization and integration of the posited integrated approach in a paper or any other texts entail methodical and comprehensive perusal of texts to expose hidden meaning lodging in clauses.

As mentioned above, these discourses such as politics, the media and advertisement, are engineered and targeted for public consumption. Due to their engineering for public consumption, adequate and eclectic use of words is an integral aspect of constructing these discourses; thereby, selection of words tends to be strategic, significant, and purposeful. This can be illustrated briefly by Wodak (1989), Cook (2003) and Locke (2004) when they point out that language may be distorted for political intentions at distinctive levels. Thus, certain words or tropes may be tactically positioned and employed with certain political objectives in mind. Likewise, definite syntactic structures of a given political discourse might be used differently hinging on the ideological and oratorical goals of "spin-doctors" and orators (speakers). Consequently, in order to investigate such discursive and pre-planned discourses, a coalescence of rigorous and interdisciplinary analytical disciplines such as SFL, CDA and Rhetoric are necessarily required. It is believed that utilizing some strategies from a single framework is a prerequisite but not a sufficient factor for inspection. Therefore, for thoroughly locating hidden ideologies in, an amalgamation of different apparatus should be applied in any texts and talks. This study is a bid to throw more light, by offering a grab bag of reasons, on the upcoming investigations to consider the posited integrated approach and to integrate various strategies for a methodical and rigorous analysis.

Additionally, the authors propose that in order to examine persuasiveness, effectiveness and eloquence of the discourses of politics, advertisement or the media, any research should include and consider such integrated approach. The present study and the analysis apparently justify and delineate that it might seem somehow cursory to study a text based on a single or some devices and also to claim its effectuality, impressiveness and competence to the audience or readers. This study, on the basis of the analysis, has shown that the integrated approach can be a salient and marked shift to a profound, critical and pragmatic investigation in political or any other various discourses. It should be born in mind that the exemplified devices in the present study are not the sole ones to critically dissect a text, and in fact, there are other apparatus such as attitudinal positioning in appraisal framework, metaphors, metonym, and other rhetorical devices etc.

To sum up, in this article we have investigated fifteen devices and sought to perceive how they function in political texts and how the speeches, as powerful and dynamic mediums, marshal thoughts and notions as a form of action. To this end, it requires to inspect how speeches both reply to and operate upon state of affairs. Criteria for employing these strategies, to name but a few, are that some tropes such as passivization and nominalization are omnipresent in political discourses leaving no trail of agents, and thereby causing obscurity and blurring in clauses which is the staple diet of nearly all political, the media and advertisement discourses. Additionally, some tools attach persuasiveness to texts, and some indicate speakers' authority or judgment etc. This approach accommodates a wealth of devices and apparatus for appraising how various tools in political speeches or other discourses are disposed tactically for particular reasons and addresses. Eventually, all these analyzed tropes reveal that politician's speeches are not ad lib at all, and all grammatical and lexical constituents are politically and religiously charged by orators for a distinctive and certain reasons to seamlessly and evenly convey intended messages to the given audience and to gain power, control and their support as well. 


\section{Acknowledgment}

The research is financed by Unique Language Centre (U. L. C.) located in Tabriz, Iran.

\section{References}

Abrams, M. H., \& Harpham, G. G. (2009). A glossary of literary terms. Boston: Wadsworth Cengage Learning.

Ali, S., \& Kazemian, B. (2015). Critical Discourse Analysis of a Reading Text "Pakistan and the Modern World": A Speech by Liaquat Ali Khan. Communication and Linguistics Studies, 1(3), 35-41.

Ali, S., Kazemian, B., \& Bughio, F. A. (2015). An investigation of the reading text "Pakistan Zindabad" (Long Live Pakistan): Critical discourse analysis perspective. Education and Linguistics Research, 1(2), $42-51$. https://doi.org/10.5296/elr.v1i2.8160

Atkins, J., \& Finlayson, A. (2014). “As Shakespeare so Memorably Said...”: Quotation, Rhetoric, and the Performance of Politics. Political Studies.

Atkinson, M. (1984). Our masters'voices: The language and body language of politics. London: Psychology Press.

Beard, A. (2000). The Language of Politics. New York, NY: Routledge.

Blommaert, J. (2005). Discourse: A Critical Introduction: Key topics in sociolinguistics. Cambridge: Cambridge University Press. https://doi.org/10.1017/CBO9780511610295

Bloor, T., \& Bloor, M. (2004). The functional analysis of English. London: Arnold.

Brown, P., \& Levinson, S. C. (1987). Politeness: Some universals in Language Usage. Cambridge: Cambridge University Press.

Butt, D., Fahey, R., Feez, S., Spinks, S., \& Yallop, C. (2000). Using functional grammar: An explorer's guide. Sydney: Macquarie University.

Cook, G. (2003). Applied linguistics. London: Oxford University Press.

De Cillia, R., Reisigl, M., \& Wodak, R. (1999). The Discursive construction of national identities. Discourse \& Society, 10(2), 149-173. https://doi.org/10.1177/0957926599010002002

Eggins, S. (2004). An introduction to systemic functional linguistics. New York/ London: Continuum.

Ehineni, T. O. (2014). A critical discourse analysis of modals in Nigerian political manifestos. International Journal of Linguistics, 6(3), 109-117. https://doi.org/10.5296/ijl.v6i3.5589

Ezeifeka, C. R. (2015). Grammatical Metaphor. SAGE Open, 5(1). https://doi.org/10.1177/2158244015577667

Fairclough, N. (2001). Language and Power. London \& New York: Longman.

Fairclough, N. (2003). Analyzing discourse: textual analysis for social research. London \& New York: Routledge.

Flowerdew, J. (2002). Rhetorical strategies and identity politics in the discourse of colonial withdrawal. Journal of Language and Politics, 1(1), 149-180. https://doi.org/10.1075/jlp.1.1.09flo

Gandio, J. D. (2008). Rhetoric for radicals: A handbook for 21st century activities. Canada: New Society Publishers.

Gunawan, S. (2010). Style of Obama’s inauguration speech. $k @ t a, \quad 12(1), \quad 92-107$. https://doi.org/10.9744/kata.12.1.92-107

Halliday, M. A. K. (1994). An introduction to functional grammar (2nd ed.). London: Edward Arnold.

Halliday, M. A. K., \& Matthiessen, C. M. I. M. (2004). An introduction to functional grammar (3rd ed.). London: Edward Arnold.

Johnstone, B., \& Eisenhart, C. (Eds.). (2008). Rhetoric in Detail: Discourse Analyses of Rhetorical Talk and Text, 31. Amsterdam: John Benjamins Publishing. https://doi.org/10.1075/dapsac.31

Jost, W., \& Olmsted, W. (2004). A companion to rhetoric and rhetorical criticism. Oxford: Blackwell Publishing. https://doi.org/10.1002/9780470999851

Kazemian, B. (2014). Hallidayan ideational grammatical metaphor in specialized texts. Germany: LAP LAMBERT Academic Publishing.

Kazemian, B. (2015). Review of the book Describing discourse: A Practical guide to discourse analysis, by 
Woods, Nicola, 2006. Asian Journal of Communication, 25(5).

Kazemian, B., \& Hashemi, S. (2014). Critical discourse analysis of Barack Obama's 2012 speeches: Views from systemic functional linguistics and rhetoric. Theory and Practice in Language Studies, 4(6), 1178-1187. https://doi.org/10.4304/tpls.4.6.1178-1187

Kazemian, B., \& Hashemi, S. (2014). Nominalizations in scientific and political genres: a systemic functional linguistics perspective. International Journal of Humanities and Social Sciences, 3(2), 211-228.

Kazemian, B., Behnam, B., \& Ghafoori, N. (2013). Ideational grammatical metaphor in scientific texts: A Hallidayan perspective. International Journal of Linguistics, 5(4), 146-168. http://dx.doi.org/10.5296/ijl.v5i4.4192

Lillian, D. L. (2008). Modality, persuasion and manipulation in Canadian conservative discourse. Critical Approaches to Discourse Analysis across Disciplines, 2(1), 1-16.

Locke, T. (2004). Critical discourse analysis. London/New York: Continuum.

Martin, J. R., Matthiessen, C. M. I. M., \& Painter, C. (1997). Working with functional grammar. London: Edward Arnold.

Murphy, J. (2003). "Our mission and our moment": George W. Bush and September 11th. Rhetoric \& Public Affairs, 6(4), 607-632. https://doi.org/10.1353/rap.2004.0013

Noor, M., Ali, M., Muhabat, F., \& Kazemian, B. (2015). Systemic Functional Linguistics Mood Analysis of the Last Address of the Holy Prophet (PBUH). International Journal of Language and Linguistics, 3(5-1), 1-9. https://doi.org/10.2139/ssrn.2604000

Noor, M., Mustafa, R., Muhabat, F., \& Kazemian, B. (2015). The Language of TV Commercials' Slogans: A Semantic Analysis. Communication and Linguistics Studies, 1(1), 7-12.

$\mathrm{Pu}$, C. (2007). Discourse analysis of President Bush's speech at Tsinghua University, China. Intercultural Communication Studies, XVI(1), 205-219. Retrieved from http://www.uri.edu/iaics/journal/index.php

Renkema, J. (2009). Discourse, of course. An Overview of Research in Discourse Studies. Amsterdam/Philadelphia: Benjamins Publishing. https://doi.org/10.1075/z.148

Richardson, J. E. (2004). (Mis) Representing Islam: The Racism and Rhetoric of British Broadsheet Newspapers, 9. Amsterdam: John Benjamins Publishing. https://doi.org/10.1075/dapsac.9

Seo, S. (2013). Hallidayean transitivity analysis: The Battle for Tripoli in the contrasting headlines of two national newspapers. Discourse \& Society, 24(6), 774-791. https://doi.org/10.1177/0957926513503267

Simon-Vandenbergen, A. M., Taverniers, M., \& Ravelli, L. (2003). Grammatical Metaphor: Views from systemic functional linguistics. Amsterdam/Philadelphia: Benjamins. https://doi.org/10.1075/cilt.236

Taverniers, M. (2002). Systemic-functional linguistics and the notion of grammatical metaphor: a theoretical study and a proposal for a semiotic-functional integrative model. Belgium: University of Gent.

Thomas, L., \& Wareing. S. (2004). Language, Society and Power. London: Routledge.

Thompson, G. (2004). Introducing functional grammar. London: Arnold.

van Dijk, T. A. (2000). Ideology and discourse: A Multidisciplinary Introduction. Barcelona: Pompeu Fabra University.

van Dijk, T. A. (2001). Critical discourse analysis. In D. Schiffrin, D. Tannen, \& H. Hamilton (Eds.), The handbook of Discourse Analysis. Oxford: Blackwell.

Wang, J. (2010). A Critical Discourse Analysis of Barack Obama's Speeches. Journal of Language Teaching and Research, 1(3), 254-261. https://doi.org/10.4304/jltr.1.3.254-261

Webster, J. J. (Ed.). (2004). The language of science. London/New York: Continuum.

Wenyan, G. (2012). Nominalization in medical papers: A comparative study. Studies in Literature and Language, 4(1), 86-93.

Wodak, R. (Ed.). (1989). Language, Power and Ideology: Studies in Political Discourse, 7. Amsterdam: John Benjamins Publishing. https://doi.org/10.1075/ct.7

Woods, N. (2006). Describing discourse: A practical guide to discourse analysis. New York: Horder Education.

$\mathrm{Xu}$, J. (2009). Interpreting metaphor of modality in advertising English. English Language Teaching, 2(4), 
117-122. https://doi.org/10.5539/elt.v2n4p117

Ye, R. (2010). The interpersonal metafunction analysis of Barack Obama's victory speech. English Language Teaching, 3(2), 146-151. https://doi.org/10.5539/elt.v3n2p146

Young, L., \& Harrison, C. (2004). Systemic functional linguistics and critical discourse analysis: Studies in social change. London/New York: Continuum.

Zhao, J. (2011). Comparative critical analysis of discourse structures. Theory and Practice in Language Studies, l(1), 108-111. https://doi.org/10.4304/tpls.1.1.108-111

Zheng, S. (2014). A critical discourse analysis of financial remarks: A case study. International Journal of English Linguistics, 4(5), 105-116. https://doi.org/10.5539/ijel.v4n5p105

Zhou, Q., \& Kazemian, B. (2015). A Rhetorical Identification Analysis of English Political Public Speaking: John F. Kennedy's Inaugural Address. International Journal of Language and Linguistics. Special Issue: Critical Discourse Analysis, Rhetoric, and Grammatical Metaphor in Political and Advertisement Discourses, 4(1-1), 10-16.

\section{Copyrights}

Copyright for this article is retained by the author(s), with first publication rights granted to the journal.

This is an open-access article distributed under the terms and conditions of the Creative Commons Attribution license (http://creativecommons.org/licenses/by/4.0/). 